\title{
Radiochronology of lake sediments
}

\author{
H. N. Erten \\ Department of Chemistry, Bilkent University, \\ 06533 Bilkent, Ankara, Turkey.
}

\begin{abstract}
Sediment cores from Lakes Zurich, Constance, from the Sea of Marmara and from southern Turkey, northern Cyprus and eastern Spain were dated using natural ${ }^{210} \mathrm{~Pb}$, fallout ${ }^{137} \mathrm{Cs}$ and cosmic-ray produced ${ }^{7} \mathrm{Be}$ radionuclides. Constant activity regions in the uppermost sections of sediments from Lake Zurich and the Sea of Marmara were attributed to postdepositional mobility of $210 \mathrm{~Pb}$ in the former case and to bioturbation in the latter. A serious discrepancy exists between the $210 \mathrm{~Pb}$ dating of Sea of Marmara sediments and those obtained by organic carbon based methods. The elements $\mathrm{Zn}, \mathrm{Cu}, \mathrm{P}$ and $\mathrm{Pb}$ were enriched in the upper sections of the sediment cores corresponding to the last 200 years. The increased metallurgical activities as a result of reforms in the Ottoman Army during the $18^{\text {th }}$ century could be the most likely cause.
\end{abstract}

\section{INTRODUCTION}

Dating of sediments combined with their chemical profile measurements allow the study of the impact of natural and cultural events on a lake and its environment. The radionuclide $210 \mathrm{~Pb}$ $\left(t_{1 / 2}=22.3 y\right)$, a member of the natural radioactive decay series of ${ }^{238} \mathrm{U}$, provides a reliable possibility of dating sediments over the last 100 years $(1,2) .{ }^{222} \mathrm{Rn}\left(\mathrm{t}_{1 / 2}=3.8 \mathrm{~d}\right)$ a noble gas in the decay series emanates from the earth's surface into the atmosphere. Decay products of ${ }^{222} \mathrm{Rn}$ including $210 \mathrm{~Pb}$ are removed from the atmosphere by dry fallout and wet precipitation, providing a continuous flux of $210 \mathrm{~Pb}$ onto land and water surfaces. In lakes and marine environment $210 \mathrm{~Pb}$ is scavenged by particulate matter and is accumulated in the sediments. Here it decays with a 22.3 year half-life and is used in dating. Besides this "unsupported" $210 \mathrm{~Pb}$ there is always a fraction of $210 \mathrm{~Pb}$ in the sediments which is in radioactive equilibrium with ${ }^{226} \mathrm{Ra}$ $\left(\mathrm{t}_{1 / 2}=1.6 \times 10^{3} \mathrm{y}\right)$. This "supported" $210 \mathrm{~Pb}$ causes a background activity which must be subtracted from the total measured ${ }^{210} \mathrm{~Pb}$ activity. The fall out nuclide ${ }^{137} \mathrm{Cs}\left(\mathrm{t}_{1 / 2}=30.1 \mathrm{y}\right)$ with its known deposition pattern resulting from extensive testing of nuclear weapons in the atmosphere between 1954-1963 and from the accident in Chernobyl in 1986 provides a complementary method of sediment dating. The maxima in fall-out corresponding to the years 1963 and 1986 are usually well preserved in sediment horizons and they can be used as time markers. This method of dating, requires complete recovery of the topmost sediment layers. ${ }^{7} \mathrm{Be}\left(\mathrm{t}_{1 / 2}=53.3 \mathrm{~d}\right) \mathrm{a}$ cosmic ray produced nuclide is expected to be present only in the uppermost sediment layers. The presence of ${ }^{7} \mathrm{Be}$ in the sediments thus ensures complete core recovery.

We have used the above mentioned radioisotopic techniques over the years for the dating of sediments from Lakes Zurich and Constance; the Sea of Marmara as well as sediments from southern Turkey and eastern Spain regions of the Mediterranean sea $(3,4,5,6)$. 


\section{EXPERIMENTAL}

Sediment cores were recovered using either a gravity corer with transparent PVC-tubes (inner diameter $6.3 \mathrm{~cm}$ ) or a box cover (Sea of Marmara Sediments). The cores were continuously sampled in 0.5-, 1- and 2-cm intervals immediately after recovery. Part of the core sections were used for textural, mineralogical and chemical studies. ${ }^{210} \mathrm{~Pb}$ was determined through its daughter 210 Po $\left(t_{1 / 2}=138.4 d\right)$ in radioactive equilibrium with its parent. About one gram of dry sample was used in each determination. ${ }^{208} \mathrm{Po}\left(\mathrm{t}_{1 / 2}=2.9 \mathrm{y}\right)$ was used as yield tracer. Polonium was distilled from the sediment at $600^{\circ} \mathrm{C}$ and converted to the chloride form by several evaporations with $\mathrm{HCl}$. It was taken into a $0.5 \mathrm{M} \mathrm{HCl}$ solution. $\mathrm{SO}_{2}$ gas was bubbled through the solution for 3 minutes at $93^{\circ} \mathrm{C}$. Polonium was self-deposited on a silver disc (diameter $0.5 \mathrm{~cm}$ ) which was suspended in the hot solution. One side of the disc was coated with RUTEX liquid rubber, ensuring deposition on one side only. An almost quantitative plating was achieved in about 7 hours. The overall chemical yield was $90 \%$ based on the ${ }^{208} \mathrm{~Pb}$ tracer. The samples were positioned in a vacuum chamber at a distance of $1 \mathrm{~mm}$ from a $\mathrm{Si}$ surface-barrier detector (ORTEC. $300 \mathrm{~mm}^{2}$ ) with an energy resolution of $20 \mathrm{keV} \mathrm{FWHM.} \mathrm{The} \mathrm{efficiency} \mathrm{for} \mathrm{the} 5.3$ $\mathrm{MeV} \alpha$-line of ${ }^{210}$ Po was determined to be $18 \pm 2 \%$. The ${ }^{210} \mathrm{Po}$ activities were converted into $210 \mathrm{~Pb}$ activities using standard growth and decay equations. In some cases $210 \mathrm{~Pb}$ was determined directly by $\gamma$-ray spectrometry via the $46.5-\mathrm{keV}$ line using a hyperpure Ge detector with $92 \mathrm{~cm}^{2}$ active area. For the ${ }^{137} \mathrm{Cs}$ and ${ }^{7} \mathrm{Be}$ measurements, the samples were freeze-dried, homogenized and were counted in a well-type $\mathrm{Ge}(\mathrm{Li})$ detector.

\section{RESULTS AND DISCUSSION}

When a dating technique is based on the decay of a radionuclide as in the case of ${ }^{210} \mathrm{~Pb}$; assuming that the flux to the sediment-water interface has remained constant and no postdepositional migration of $210 \mathrm{~Pb}$ has occurred; the activity in the sediment is given by;

$$
\begin{aligned}
& \mathrm{A}(\mathrm{z})=\mathrm{A}_{\mathrm{o}} \mathrm{e}^{-\lambda \mathrm{z} / \mathrm{s}} \\
& \text { Here; } \\
& \mathrm{A}(\mathrm{z}) \text { : activity of unsupported } 210 \mathrm{~Pb} \text { at depth } \mathrm{z}(\mathrm{dpm} / \mathrm{g}) \\
& \mathrm{A}_{\mathrm{o}}=\mathrm{F} / \mathrm{s} \text { : initial activity of } 210 \mathrm{~Pb}(\mathrm{dpm} / \mathrm{g}) \\
& \mathrm{s} \text { : mass sedimentation rate }\left(\mathrm{g} \cdot \mathrm{cm}^{-2} \cdot \mathrm{y}^{-1}\right) \\
& \mathrm{z} \text { : mass depth }\left(\mathrm{g} \cdot \mathrm{cm}^{-2}\right) \\
& \lambda \text { : decay constant of } 210 \mathrm{~Pb}\left(\mathrm{y}^{-1}\right) \\
& \mathrm{F} \text { : flux of } 210 \mathrm{~Pb}\left(\mathrm{dpm} \cdot \mathrm{cm}^{-2} \cdot \mathrm{y}^{-1}\right)
\end{aligned}
$$

If it is further assumed that $A_{0}$ is constant a logarithmic plot of unsupported $210 \mathrm{~Pb}$ activity against depth, yields both the sedimentation rate $\mathrm{S}$ and flux $\mathrm{F}$. Linear and mass sedimentation rates are related as;

$$
\begin{aligned}
& s=r .(1-\phi) \cdot \rho_{s} \\
& \text { Where; } \\
& s: \text { mass sedimentation rate }\left(\mathrm{g} . \mathrm{cm}^{-2} \cdot \mathrm{y}^{-1}\right) \\
& \mathrm{r} \text { : linear sedimentation rate }\left(\mathrm{cm} \cdot \mathrm{y}^{-1}\right) \\
& \phi: \text { porosity } \\
& \rho: \text { sediment density }\left(\mathrm{g} \cdot \mathrm{cm}^{-3}\right)
\end{aligned}
$$

Sediment compaction is taken into account by using mass depth and correspondingly mass sedimentation rates.

When the sedimentation rate is variable in time but the flux $210 \mathrm{~Pb}$ remains constant the correspondence between age and depth is given by the relation; 
$t(z)=1 / \lambda \ln \left(\sum_{0}^{\infty} A(z) / \sum_{z}^{-} A(z)\right)$

Here;

$t(z)$ : age of the sediment at depth $z(y)$

$\sum_{0}^{-} A(z)$ : total integrated $210 \mathrm{~Pb}$ activity below the sediment-water interface $\left(\mathrm{dpm} . \mathrm{cm}^{-2}\right)$

$\sum_{\Sigma} A(z)^{\Sigma \mathrm{A}(\mathrm{z}): \text { integrated }{ }^{210} \mathrm{~Pb} \text { activity below depth } \mathrm{z}\left(\mathrm{dpm} . \mathrm{cm}^{-2}\right)}$

The atmospheric fallout pattern of ${ }^{137} \mathrm{Cs}(9)$ and the vertical distribution of ${ }^{137} \mathrm{Cs}$ in a sediment core from Northern Cyprus are shown in Figs. la and $1 \mathrm{~b}$ respectively. The 1963 (nuclear tests) and 1986 (Chernobyl accident) horizons are clearly observed allowing the determination of sedimentation rates complementing those obtained from the $210 \mathrm{~Pb}$ method.
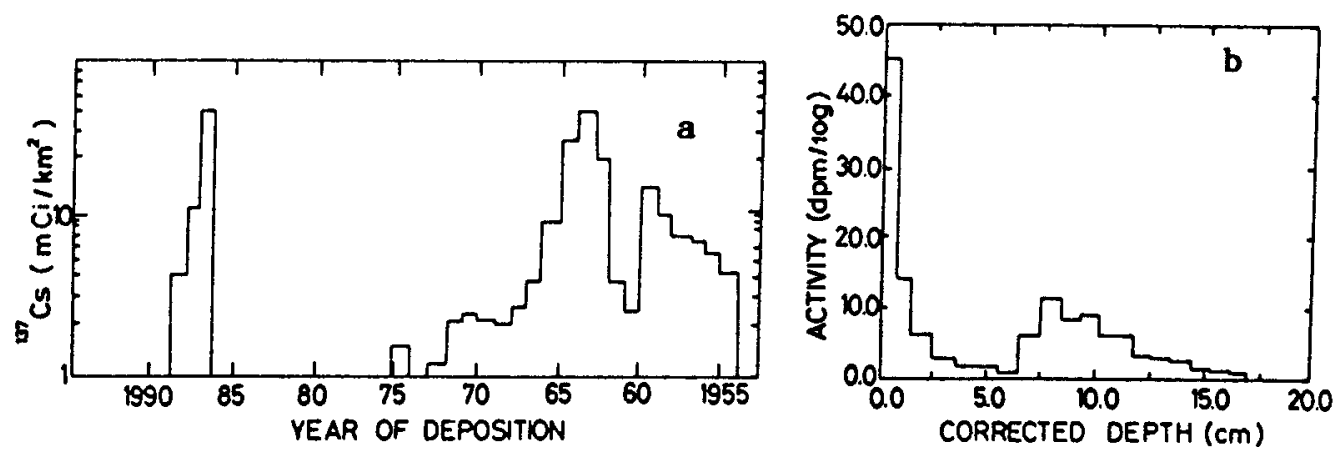

Fig.1. The atmospheric fallout curve of ${ }^{137} \mathrm{Cs}$ (a) and the vertical distribution of ${ }^{137} \mathrm{Cs}$ in a sediment core from Northern Cyprus (b) recovered in 1989.

The experimental total $210 \mathrm{~Pb}$ activities for various sediment cores are shown in Fig.2. The total activities consist of an essentially constant "supported" fraction in the deeper regions and an excess "unsupported" activity which decreased with depth. The "supported" $210 \mathrm{~Pb}$ may be assumed to be constant within the length of the core. In the case of Lake Zurich and Sea of Marmara sediments; it is observed that there is a plateau region in the uppermost sediment sections extending to about $2 \mathrm{~g} \cdot \mathrm{cm}^{-2}$ and $3 \mathrm{~g} . \mathrm{cm}^{-2}$ depths respectively. Such kind of constant activity regions are commonly reported in the literature (7). They are explained by various mixing models assuming chemical, biological or physical mixing processes.

In the case of Lake Zurich sediments the plateau region could not be explained by any kind of mixing process for the following reasons. First, the distribution of fallout ${ }^{137} \mathrm{Cs}$ showed a distinct maximum at about $1.5 \mathrm{~g} . \mathrm{cm}^{-2}$ depth; second texture analysis of the cores showed well developed annual layers with a succession of distinct light (summer) and black (winter) laminations. The dark laminae represent organic rich ooze, containing residues of phytozooplankton communities of a year. The light layers are formed from calcite crystals which precipitate during spring/early summer at the time of high productivity in hard-water lakes of humid climate. The interval between two light layers represent one year. Furthermore the inventory of $210 \mathrm{~Pb}$ in the sediment profiles amounted to about $50 \%$ of the expected input assuming an atmospheric flux of $0.9 \mathrm{dpm} . \mathrm{cm}^{-2} \cdot \mathrm{y}^{-1}(8)$. Possible remobilization of $210 \mathrm{~Pb}$ through the pore water may explain these observations. Wan et al.'s (9) later measurements of $210 \mathrm{~Pb}$ concentrations in pore waters of Lake Zurich sediments support our explanation. 


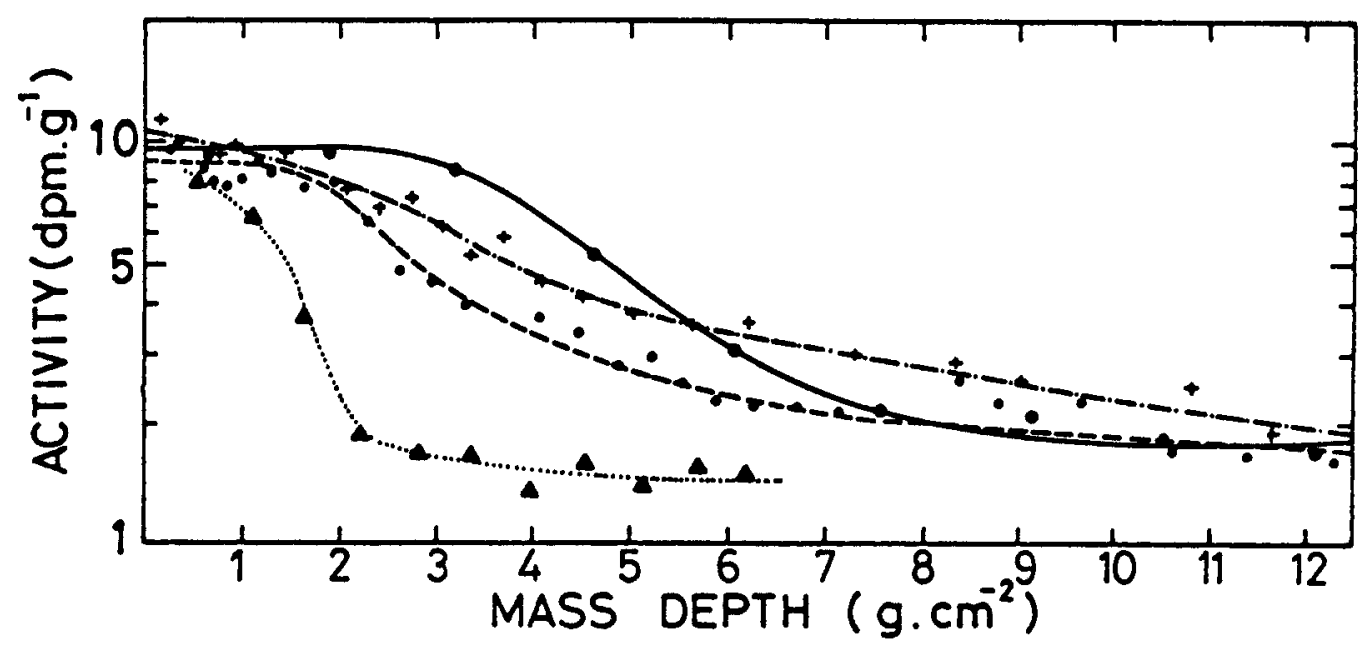

Fig.2. Measured total $1210 \mathrm{~Pb}$ activities of sediment cores. o Lake Zurich, + Lake Constance, - Sea of Marmara, $\Delta$ Southern Turkey

The inventory of ${ }^{210} \mathrm{~Pb}$ in the Sea of Marmara sediments was about $80 \%$ of the expected input. No evidence of lamination was observed. SEM studies indicated the existence of microorganisms (coccoliths) and radiographic studies showed burrowed structures (5). Based on these observations, bioturbation was probably the most significant process producing the constant activity region in the sediments of the Sea of Marmara.

TABLE 1. Summary of Sedimentation Rates Obtained in our Studies at Various Regions, Using Different Dating Methods.

\begin{tabular}{l|c|c|c|c}
\hline \multirow{2}{*}{\multicolumn{1}{c|}{$\begin{array}{c}\text { Sediment } \\
\text { Core }\end{array}$}} & \multicolumn{4}{c}{$\begin{array}{c}\text { Mass Sedimentation Rate } \\
\left(\mathrm{g} \cdot \mathrm{cm}^{-2} \cdot \mathrm{y}^{-1}\right)\end{array}$} \\
\cline { 2 - 5 } & $\begin{array}{c}210 \mathrm{~Pb} \\
\text { Method }\end{array}$ & $\begin{array}{c}137 \mathrm{Cs} \\
\text { Time } \\
\text { Marker }\end{array}$ & $\begin{array}{c}\text { Varve } \\
\text { Counting }\end{array}$ & $\begin{array}{c}\text { Sediment } \\
\text { Traps }\end{array}$ \\
\hline Lake Zurich & $0.073 \pm 0.015$ & $0.07 \pm 0.01$ & $0.07 \pm 0.02$ & - \\
Lake Constance & $0.11 \pm 0.02$ & $0.09 \pm 0.01$ & - & $0.14 \pm 0.09$ \\
Sea of Marmara & $0.087 \pm 0.012$ & - & - & - \\
Southern Turkey & $0.083 \pm 0.013$ & - & - & - \\
Eastern Spain & $0.21 \pm 0.02$ & $0.13 \pm 0.02$ & - & - \\
North Cyprus & $0.17 \pm 0.03$ & $0.19 \pm 0.02$ & - & - \\
\hline
\end{tabular}

Sedimentation rates obtained in our studies are summarized in Table 1. The results of three different methods agree quite well in the dating of Lake Zurich Sediments. Distinct annual varves allowing rate determinations were not observed in the sediment cores from the other regions. Sediment traps were used only in Lake Constance and the rate obtained agrees reasonably well with those of ${ }^{210} \mathrm{~Pb}$ and ${ }^{137} \mathrm{Cs}$ methods. The ${ }^{137} \mathrm{Cs}$ profiles did not reveal a clear distribution pattern that could allow dating in the case of sediment cores from Sea of Marmara and southern Turkey. The inventories of ${ }^{137} \mathrm{Cs}$ in these sediment profiles were very low compared to the atmospheric fall out input. Such low inventories have also been observed in 
other lake sediments (10). Resuspension and/or dissolution processes causing the recycling of the sedimentary ${ }^{137} \mathrm{Cs}$ in the water column may be the likely cause of the observed patterns and inventories. Another likely reason is the loss of the uppermost sections during coring. The sedimentation rates at different regions of the Mediterranean Sea given in Table 1 are strikingly higher than those of the lakes. This unexpected result is believed to be due to the fact that the sediment cores were recovered very near the shores.

Stanley and Blanpied (11) used ${ }^{14} \mathrm{C}$ method for dating sediment cores from the Sea of Marmara taken in the same region as those of this work. Their sedimentation rates range from 0.0034 $\mathrm{cm} \cdot \mathrm{y}^{-1}$ to $0.019 \mathrm{~cm} \cdot \mathrm{y}^{-1}$. Pastouret (12) dated Aegean sea sediments using ${ }^{14} \mathrm{C}$. His results vary from $0.0080 \mathrm{~cm} \cdot \mathrm{y}^{-1}$ to $0.0120 \mathrm{~cm} . \mathrm{y}^{-1}$. Recently Ergin et al. (13) determined sedimentation rates of several sediment samples from various regions of the Sea of Marmara using the MuellerSuess empirical formula based on the organic carbon content of the sediments and annual primary production data. Their mean sedimentation rate of twelve sediment samples from the northeastern section is $0.067 \mathrm{~cm} . \mathrm{y}^{-1}$. Our result of $0.12 \pm 0.02 \mathrm{~cm} . \mathrm{y}^{-1}$ based on $210 \mathrm{~Pb}$ method is not in agreement with these reported values. It indicates much higher rates, at least during the last 100 years. ${ }^{14} \mathrm{C}$ based methods give sedimentation rates corresponding to historical averages of thousands of years. The results of organic carbon and calcium carbonate measurements of our cores indicate that their amount as well as their ratio did not change significantly along the sediment profile up to about one meter depth. This makes changes in the sedimentation rate unlikely within this depth, at least if different sources for the two carbon types are assumed. Thus organic carbon based methods seem to be not applicable in this case probably due to significant loss of organic carbon into the overlying water and/or within the sediments.

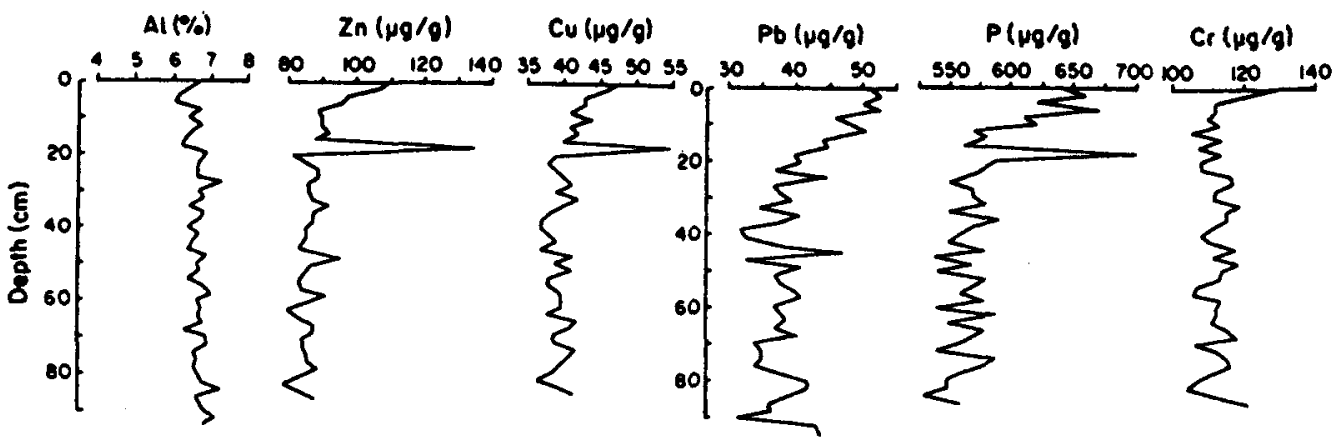

Fig.3. Distribution of $\mathrm{Al}, \mathrm{Cu}, \mathrm{Zn}, \mathrm{Pb}, \mathrm{P}$ and $\mathrm{Cr}$ in sediment cores of the Sea of Marmara.

Analysis of various elements throughout the sediment cores of the Sea of Marmara were made using ICP-AES. Fig. 3 show the distribution of $\mathrm{Al}, \mathrm{Cu}, \mathrm{Zn}, \mathrm{Pb}, \mathrm{Cr}$ and $\mathrm{P}$ in sediments of the Sea of Marmara. The elements $\mathrm{Zn}, \mathrm{Cu}, \mathrm{P}$, and possibly $\mathrm{Pb}$ show near surface enrichment in the upper parts of the cores, corresponding to the last 200 years as indicated by $210 \mathrm{~Pb}$ dating. The increase in content of these trace elements could be due to natural causes i.e. change of source material because of uncovering of new rock types or changes in drainage patterns. However since no significant change was observed in organic and inorganic carbon contents throughout the cores; the above mentioned natural causes seem unlikely, suggesting enrichment due to anthropogenic causes. Towards the end of the eighteenth century, great changes were introduced in the Ottoman Army and Navy. New foundries, armament works, and shipyards were being constructed in and around Istanbul. This activity could be responsible for the enrichment of certain metal contents of the sediments. 


\section{REFERENCES}

1. E.D. Goldberg, Radioactive Dating, LAEA STLPUB/68, 121 (1963).

2. J.A. Robbins, Geochemical and Geophysical Applications of Radioactive Lead, in Biogeochemistry of Lead, Chapter 9, J.P. Nriagu (Ed.), Elsevier (1978).

3. H.N. Erten, H.R. von Gunten, E. Rössler and M. Sturm, Schweiz. Z.Hydrol. 47, 5 (1985).

4. H.R. von Gunten, M. Sturm, H.N. Erten, E. Rössler and F. Wegmüller, Schweiz. Z. Hydrol. 49, 275 (1987).

5. G. Evans, H.N. Erten, S.A. Alavi, H.R. von Gunten and M. Ergin, Geo-Marine Letters 9, 27 (1989).

6. S. Tadjiki and H.N. Erten, J. Radioanal. Nucl. Chem. 181, 447 (1994).

7. J.A. Robbins and D.N. Edgengton, Geochim. Cosmochim. Acta 39, 285 (1975).

8. K.K. Turekian, L.K. Beninger and E.P. Dion, J. Geophys. Res. 88, (C9), 5411 (1983).

9. G.J. Wan, P.H. Santschi, M. Sturm, K. Farrenkothen, A. Lueck, E. Werth and Ch. Schuler, Chem. Geol. 63 (1987).

10. G.J. Brunskill, S.D. Ludlam and T. -H. Peng, Chem. Geology 44, 101 (1984).

11. D.J. Stanley and C. Blanpied, Nature 285, 537 (1980).

12. L. Pastouret, Tethys. 2, 227 (1970).

13. M. Ergin, M.N. Bodur, M. Yıldız, D. Ediger, V. Ediger, S. Yemenicioğlu and F. Yücesoy, Continental Shelf Research 14, 1371 (1994). 